\title{
Improving the Hybrid Photovoltaic/Thermal System Performance Using Water-Cooling Technique and $\mathrm{Zn}-\mathrm{H}_{2} \mathrm{O}$ Nanofluid
}

\author{
Hashim A. Hussein, Ali H. Numan, and Ruaa A. Abdulrahman \\ Electromechanical Engineering Department, University of Technology, Baghdad, Iraq \\ Correspondence should be addressed to Hashim A. Hussein; hashim171967@gmail.com
}

Received 2 October 2016; Revised 20 December 2016; Accepted 16 January 2017; Published 2 May 2017

Academic Editor: Md. Rabiul Islam

Copyright (c) 2017 Hashim A. Hussein et al. This is an open access article distributed under the Creative Commons Attribution License, which permits unrestricted use, distribution, and reproduction in any medium, provided the original work is properly cited.

\begin{abstract}
This paper presented the improvement of the performance of the photovoltaic panels under Iraqi weather conditions. The biggest problem is the heat stored inside the PV cells during operation in summer season. A new design of an active cooling technique which consists of a small heat exchanger and water circulating pipes placed at the PV rear surface is implemented. Nanofluids $(\mathrm{Zn}-\mathrm{H} 2 \mathrm{O})$ with five concentration ratios $(0.1,0.2,0.3,0.4$, and $0.5 \%)$ are prepared and optimized. The experimental results showed that the increase in output power is achieved. It was found that, without any cooling, the measuring of the PV temperature was $76^{\circ} \mathrm{C}$ in 12 June 2016; therefore, the conversion efficiency does not exceed more than 5.5\%. The photovoltaic/ thermal system was operated under active water cooling technique. The temperature dropped from 76 to $70^{\circ} \mathrm{C}$. This led to increase in the electrical efficiency of $6.5 \%$ at an optimum flow rate of $2 \mathrm{~L} / \mathrm{min}$, and the thermal efficiency was $60 \%$. While using a nanofluid $(\mathrm{Zn}-\mathrm{H} 2 \mathrm{O})$ optimum concentration ratio of $0.3 \%$ and a flow rate of $2 \mathrm{~L} / \mathrm{min}$, the temperature dropped more significantly to $58^{\circ} \mathrm{C}$. This led to the increase in the electrical efficiency of $7.8 \%$. The current innovative technique approved that the heat extracted from the PV cells contributed to the increase of the overall energy output.
\end{abstract}

\section{Introduction}

Photovoltaic (PV) systems represent a solution for the problem of low carbon, nonfossil fuel used to generate electricity. Solar radiation absorbed and converted by semiconductor devices (solar cells) can provide a supply of electricity to meet energy needs. An energy source with less emissions of carbon, no dependence on fossil fuels, massive potential for developing countries, and well suited to be distributed, PV, is considered as a medium and long range energy prospect as presented by Firth [1]. The photovoltaic system has advantages compared to other systems, such as low maintenance, unattended operation, reliable long life between 20 and 30 years, no fuel and no fumes, easy to install, and low recurrent costs as presented by Oi [2]. Basically, the solar $\mathrm{PV} / \mathrm{T}$ system can be broadly categorized into two systems: photovoltaic and solar thermal system. The PV/T system refers to a system that uses heat transfer fluid to extract heat from the panel. The fluid is water or air and sometimes both. The photovoltaic thermal system (PV/T) has been developed for several reasons; one of the main reasons is that the PV/T system can give higher efficiency than PV alone and thermal collector system as presented by Teo [3]. The application of nanofluid in solar collectors leads to a homogeneous temperature distribution inside the receiver. In addition, greater light absorption, a high absorption at visible wavelengths, and a low emissivity at infrared wavelengths can be achieved, and sunlight can be directly converted into useful heat as presented by Taylor et al. [4]. Nanoparticles have the following advantages in solar power plants: (1) the extremely small size of the particles ideally allows them to pass through pumps and plumbing without adverse impacts, (2) nanofluids can absorb energy directly skipping intermediate heat transfer steps, (3) the nanofluids can be optically selective (i.e., high absorption in the solar range and low remittance in the infrared), (4) a more uniform receiver temperature can be achieved inside the collector (reducing material constraints), (5) enhanced heat transfer via greater convection and thermal conductivity may enhance receiver performance, and (6) absorption efficiency may be improved by tuning the 


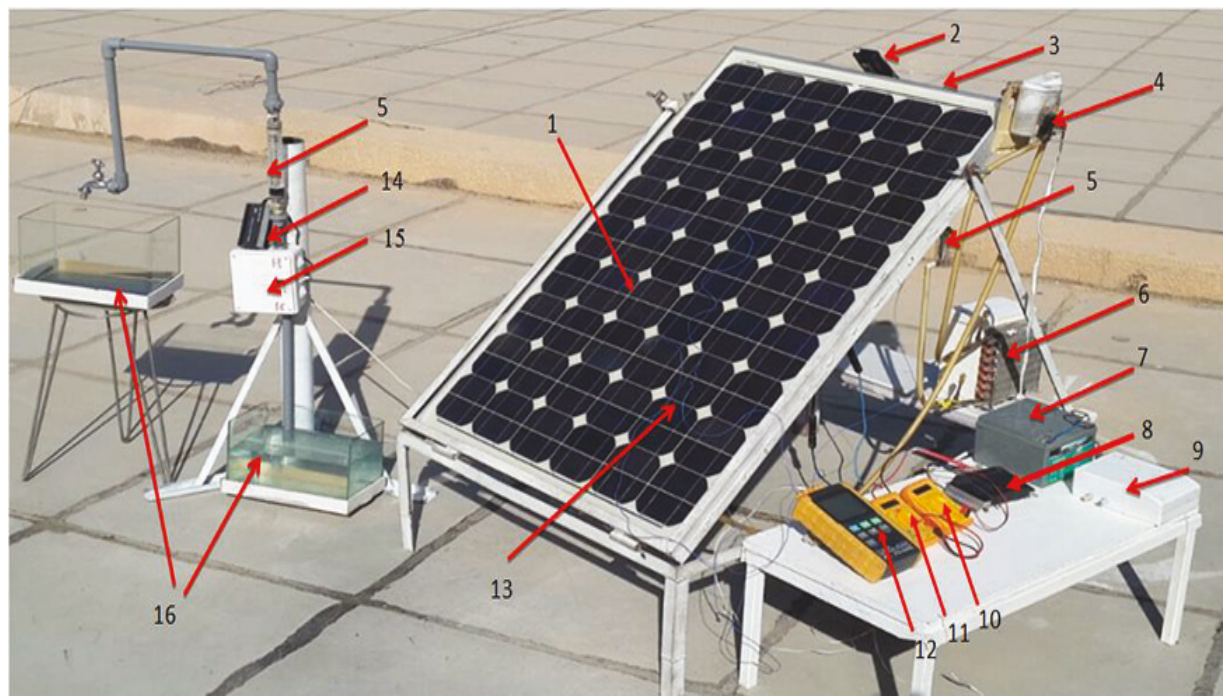

(1) Photovoltaic panel (PV), (2) solar meter, (3) oscillatory collector (copper pipes), (4) DC pump, (5) flow meters (number 2), (6) heat exchanger, (7) battery, (8) charge controller, (9) voltage regulator, (10) ammeter, (11) voltmeter, (12) temperature recorder, (13) thermocouple, (14) boost converter, (15) DC pump circulation, (16) water tank (number 2).

(a)

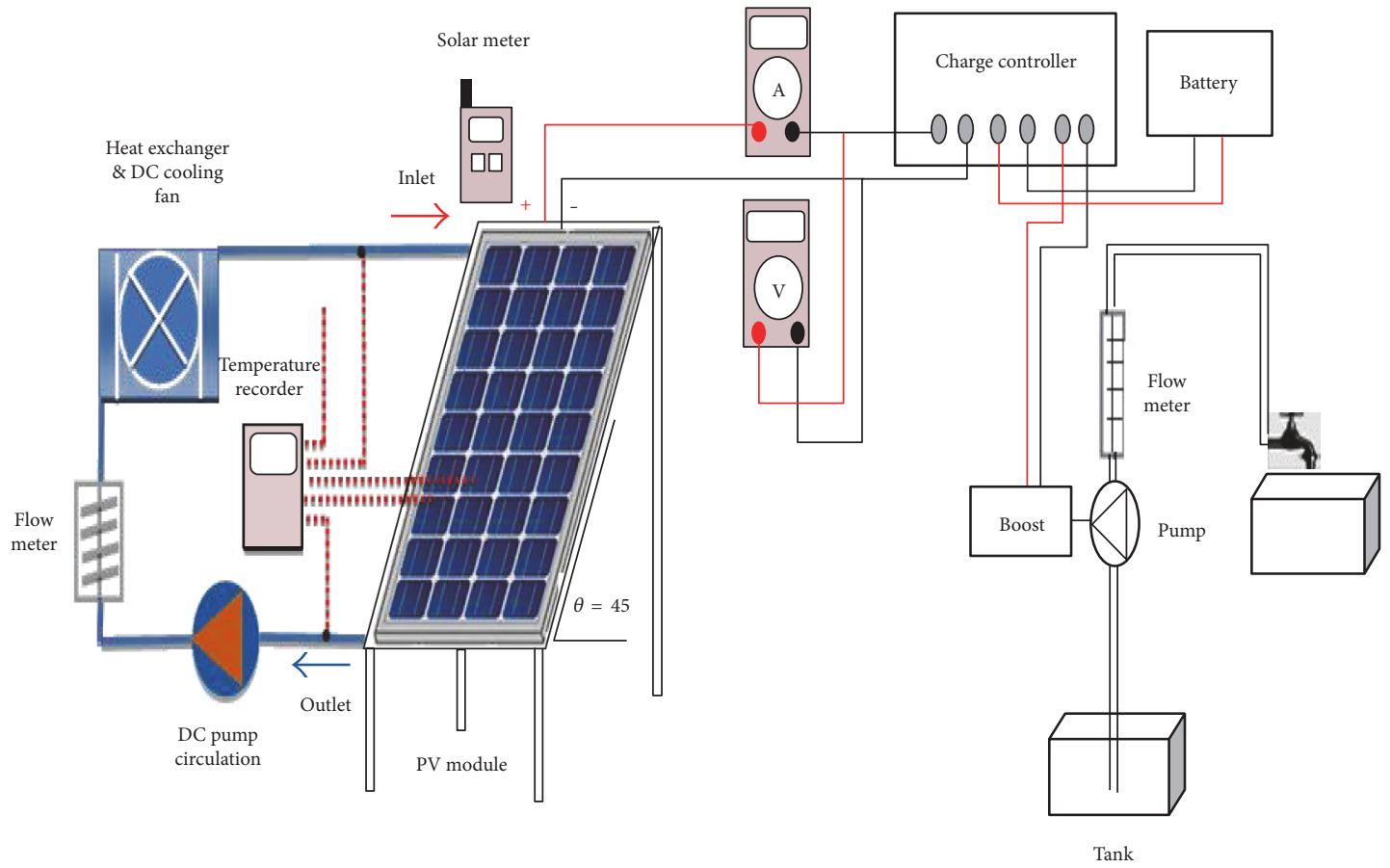

(b)

Figure 1: Photograph (a) and schematic diagram (b) of the experimental setup.

nanoparticle size and shape that suit the application as presented by Abdolzadeh and Ameri [5].

EL-Basit et al. [6] investigated a simple one-diode mathematical model, by applying a MATLAB script. The results showed that the variation in irradiation mainly affects the output current, while the variations in temperature mainly affect the output voltage. Odeh and Behnia [7] developed a cooling technique by trickling water on the upper surface of a PV module to improve the performance of a proposed PV pumping system. The results of their experimental rig showed that an increase of about $15 \%$ in the output of the system was achieved at peak radiation conditions due to the heat loss by convection between the water and the upper surface of the PV panel. Long-term performance of the system was estimated by integrating the test results in a commercial transient simulation package using the data of site radiation and ambient temperature. The simulation results of annual performance of system showed an increase of $5 \%$ in delivered energy from the PV module during dry and warm seasons. 


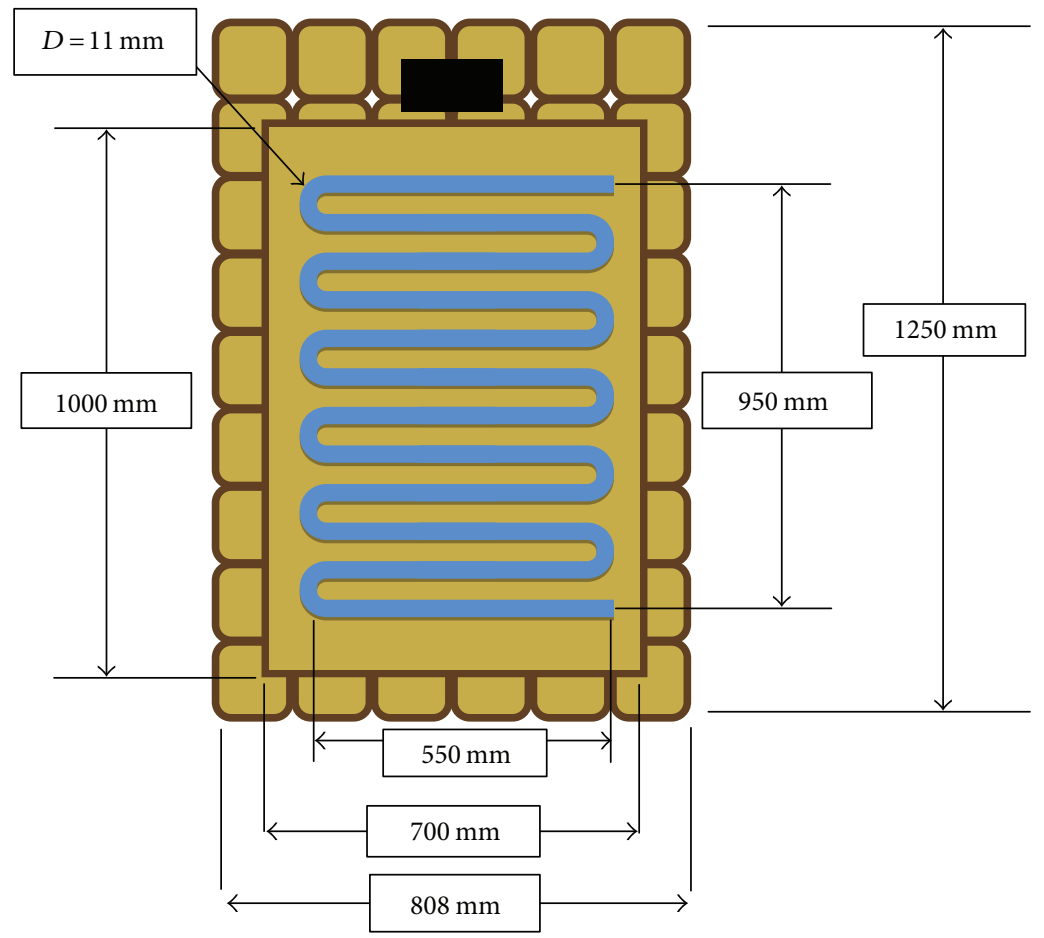

(a)
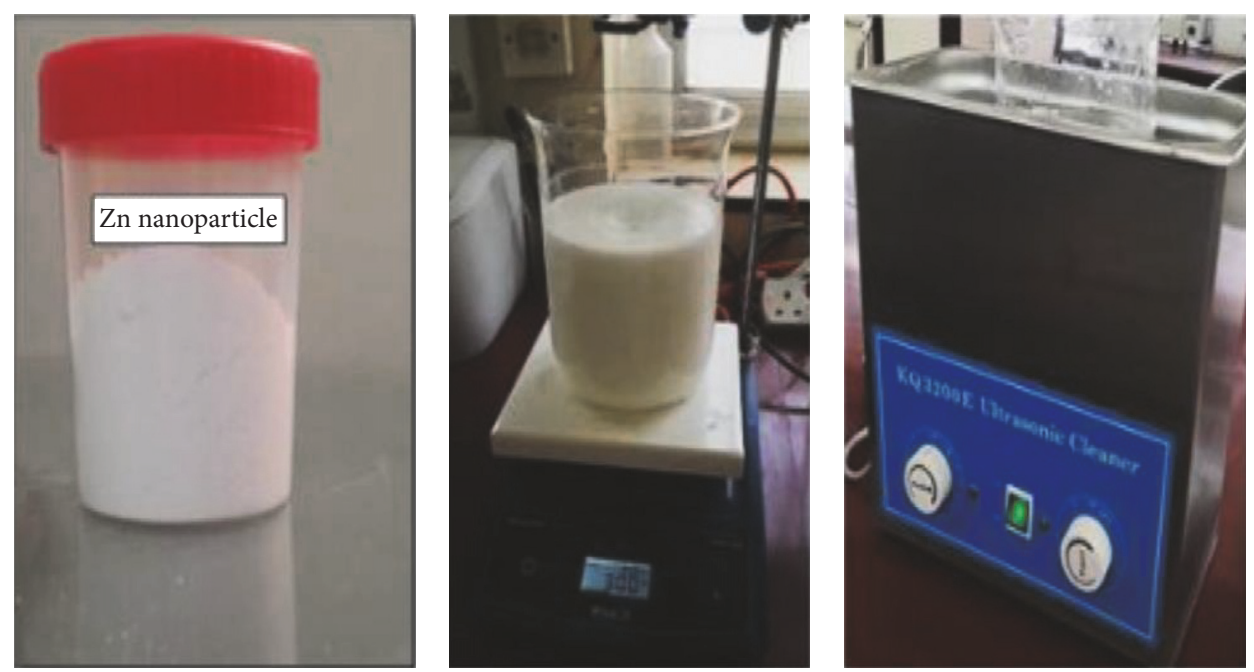

(b)

Figure 2: (a) Dimensions of thermal pipes mounted on the backside of PV. (b) Steps of nanofluid preparation.

Chaji et al. [8] studied the effect of various concentrations of $\mathrm{TiO}_{2}$ nanoparticles in water with three values of flow rates, namely, 36, 72, and $108 \mathrm{~L} / \mathrm{hr}$. They investigated four particles' concentration ratios $(0,0.1,0.2$, and $0.3 \%$ wet $)$. The results showed that adding nanoparticles to water increased the initial efficiency of flat plate solar collector by 3.5 to $10.5 \%$ and the index of collector total efficiency by 2.6 to $7 \%$ relative to that of the base fluid.

The major problem in PV is the accumulation of heat, which reduces the electrical performance obviously; therefore, heat must be dissipated. In Iraq, the problem becomes much serious, because of a hot weather in most of the year; this makes the electrical efficiency of PV cells to decrease with the increase of the heat inside the PV cells. The active solution for this problem can be using a water-cooling technique to decrease the heat effects by transferring the heat to the water which can be used in many applications as a hot water. Thermal conductivity enhancement can be achieved by using nanofluid applications such as $\mathrm{Zn}$ $\mathrm{H}_{2} \mathrm{O}$. The originality of the current work is the use of a new design of a cooling technique including copper pipes placed on PV rear surface to absorb the heat accumulated inside the PV cells. This aim was achieved through evaluation of the performance of photovoltaic panels 


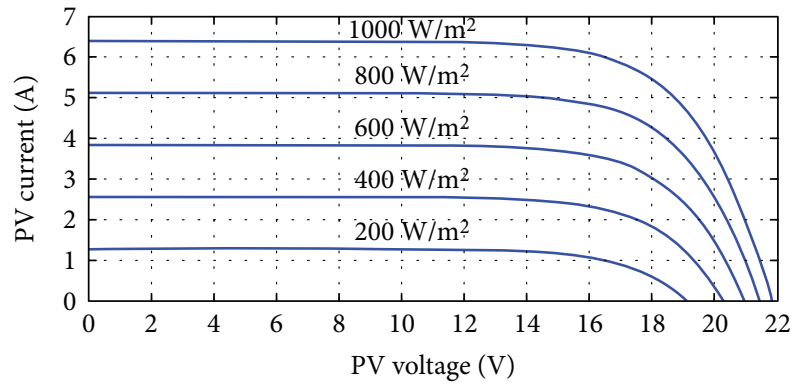

(a)

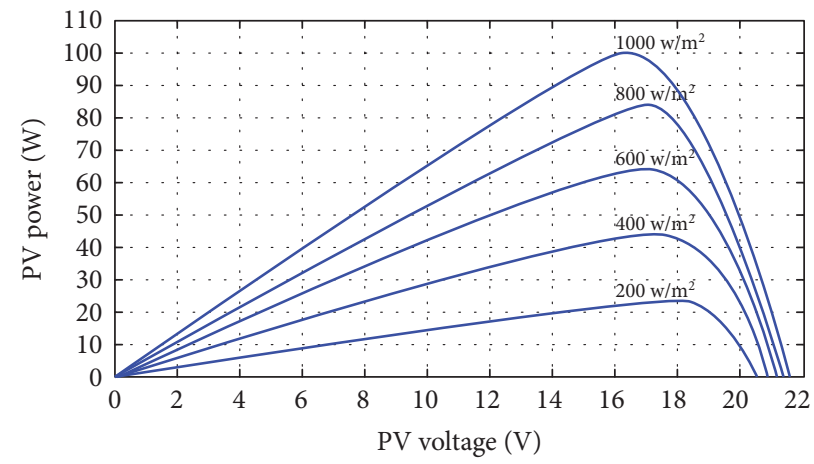

(c)

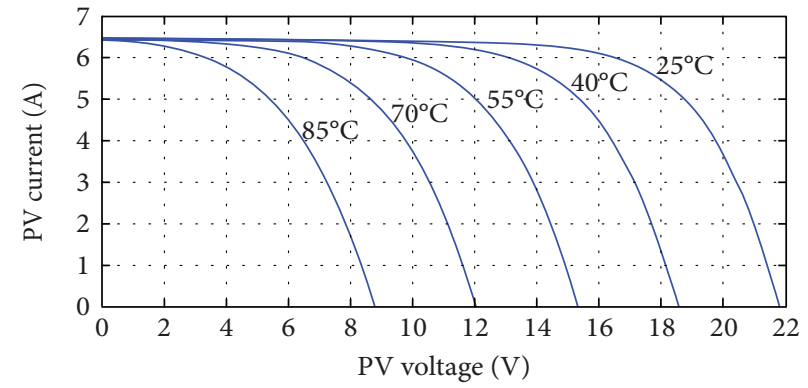

(b)

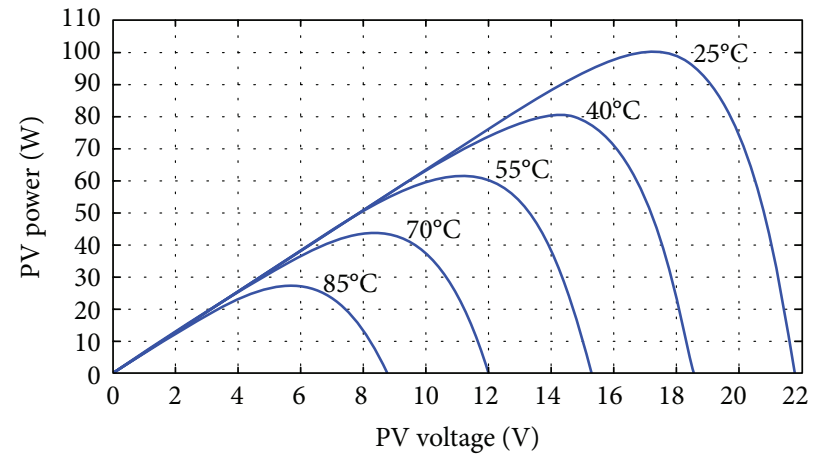

(d)

Figure 3: (a) Theatrical $I-V$ characteristics with radiation at constant temp. $\left(25^{\circ} \mathrm{C}\right)$. (b) $P-V$ characteristics with radiation at constant temp. $\left(25^{\circ} \mathrm{C}\right)$. (c) $I-V$ characteristics with temperature at constant radiation $\left(1000 \mathrm{~W} / \mathrm{m}^{2}\right)$. (d) $P-V$ characteristics with temperature at constant radiation $\left(1000 \mathrm{~W} / \mathrm{m}^{2}\right)$.

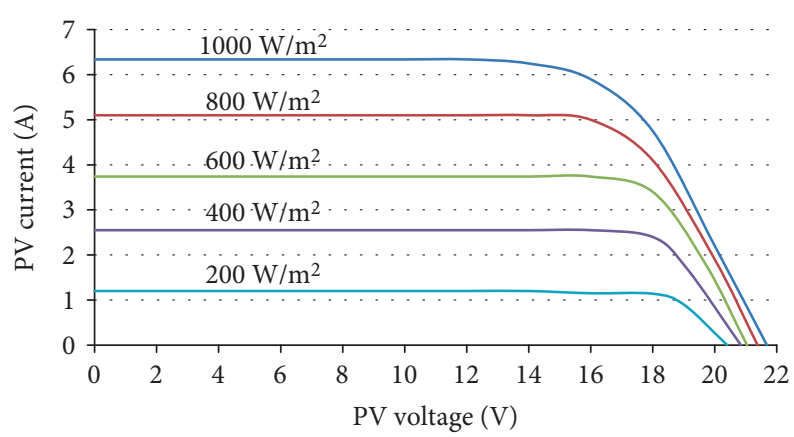

(a)

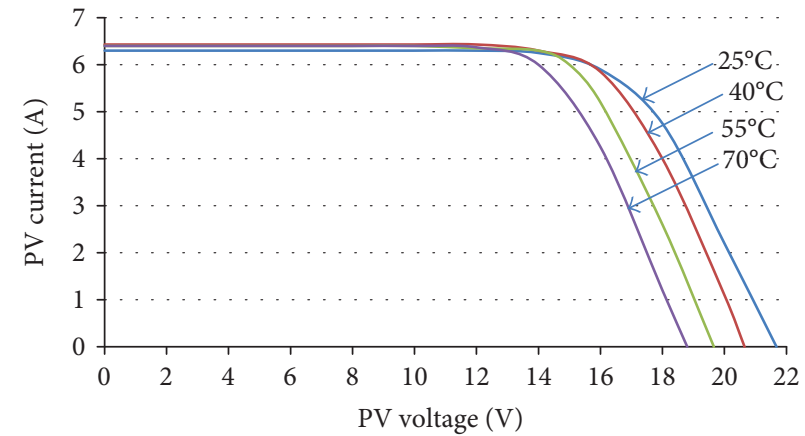

(b)

FIgURE 4: (a) Experimental $I$ - $V$ characteristics with radiation at constant temp. $\left(25^{\circ} \mathrm{C}\right)$. (b) $I-V$ characteristics with temp. at constant radiation $\left(1000 \mathrm{~W} / \mathrm{m}^{2}\right)$.

under different operating conditions, enhancement of the electrical and thermal performance for the photovoltaic/ thermal system with water pumping system at different water mass flow rates, and studying the effect of using nanofluid ( $\mathrm{Zn}$ ) as a working fluid in water-circulating pipes at different concentration ratios $(0.1,0.2,0.3,0.4$, and 0.5 ).

\section{Mathematical Modeling}

2.1. Overall Performance of PV/T System. The equations of the nominal electrical efficiency $\left(\eta_{0}\right)$ presented by Ben [9] are as follows:

$$
\begin{aligned}
\eta_{0} & =\frac{V_{\mathrm{mp}} I_{\mathrm{mp}}}{G A}, \\
\eta_{\text {elec }} & =\eta_{0}\left[1-\beta\left(T_{\mathrm{c}}-T_{0}\right)\right], \\
Q & =m C_{\mathrm{P}}\left(T_{0}-T_{\mathrm{i}}\right) .
\end{aligned}
$$

The thermal efficiency is evaluated by the following equations, presented by El-Seesy et al. [10]:

$$
\begin{gathered}
\eta_{\text {th }}=\frac{m \cdot c p\left(T_{0}-T_{\mathrm{i}}\right)}{A_{\mathrm{c}} G}, \\
\eta_{\text {total }}=\eta_{\text {th }}+\eta_{\text {elec }}=\frac{m c p \int\left(T_{0}-T_{\mathrm{i}}\right) d t+\int V I d t}{A_{\mathrm{c}} \int G(t) d t} .
\end{gathered}
$$




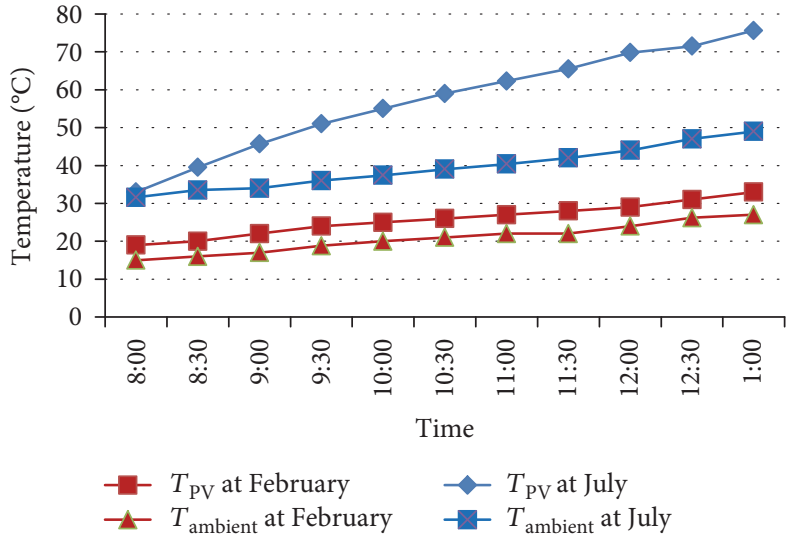

(a)

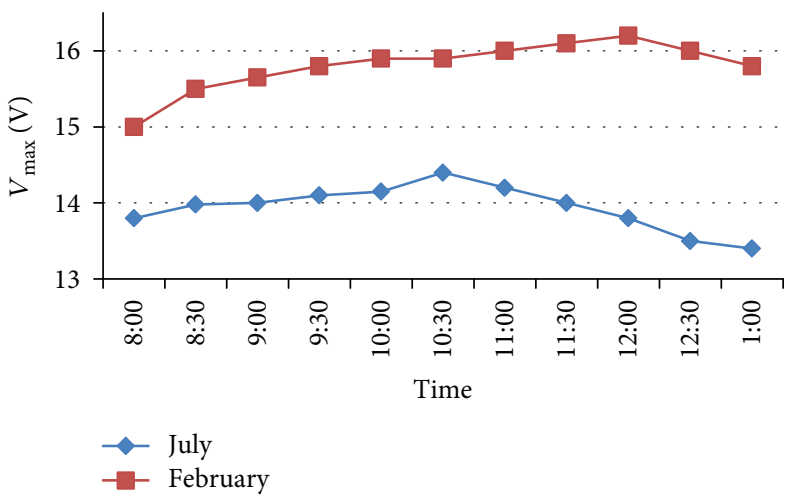

(b)

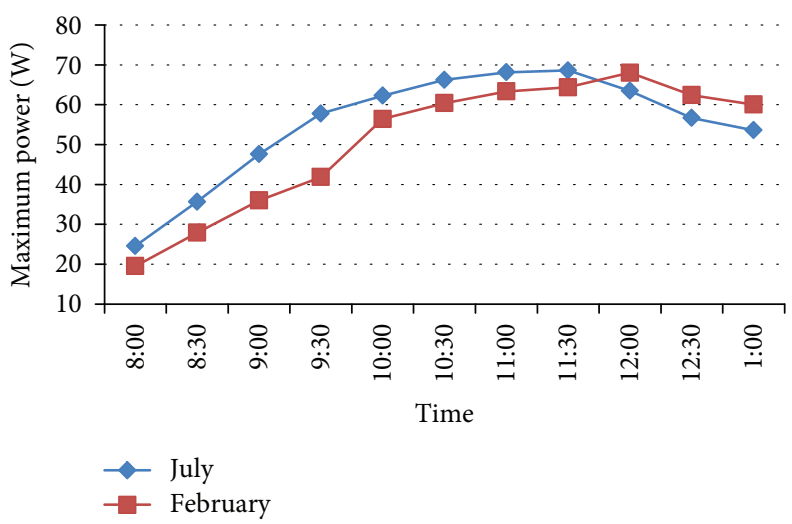

(c)

FIgUre 5: (a) Temperature variations at climatic conditions. (b) Comparison between the voltages at climatic conditions. (c) Comparison between the output powers at climatic conditions.

2.2. Thermophysical Properties of $\mathrm{Zn}-\mathrm{H}_{2} \mathrm{O}$ Nanofluid. Thermophysical properties of the working fluid $\left(\mathrm{Zn}-\mathrm{H}_{2} \mathrm{O}\right.$ nanofluid) are changed due to influence of the nanoparticles. These properties for conventional fluids can be found from standard tables or equations as presented by Darby [11]. The properties of nanofluids can be estimated by using the following equations, as presented by Albadr and Hussein [12, 13]:

$$
\begin{aligned}
\rho_{\mathrm{nf}} & =(1-\phi) \rho_{\mathrm{f}}+\phi \rho_{\mathrm{p}}, \\
(\rho C p)_{\mathrm{nf}} & =(1-\phi)(\rho C p)_{\mathrm{f}}+\phi(\rho C p)_{\mathrm{p}}, \\
\mu_{\mathrm{nf}} & =(1+2.5 \phi) \mu_{\mathrm{w}}, \\
K_{\mathrm{nf}} & =\left[\frac{K_{\mathrm{p}}+2 K_{\mathrm{f}}-2\left(K_{\mathrm{f}}-K_{\mathrm{p}}\right) \phi}{K_{\mathrm{p}}+2 K_{\mathrm{f}}-\left(K_{\mathrm{f}}-K_{\mathrm{p}}\right) \phi}\right] K_{\mathrm{f}}, \\
\phi & =\frac{m_{\mathrm{p}} / \rho_{\mathrm{p}}}{\left(m_{\mathrm{p}} / m_{\mathrm{p}}\right)+\left(m_{\mathrm{f}} / \rho_{\mathrm{f}}\right)}, \\
\propto_{\mathrm{nf}} & =\frac{K_{\mathrm{nf}}}{\rho_{\mathrm{nf}} C p_{\mathrm{nf}}}, \\
\nu & =\frac{\mu}{\rho} .
\end{aligned}
$$

Calculation of Reynolds, Peclet, and Prandtl numbers is as follows [13]:

$$
\begin{aligned}
& \operatorname{Re}=\frac{V D}{v}, \\
& \operatorname{Pe}=\frac{V D}{\propto_{\mathrm{nf}}}, \\
& \operatorname{Pr}=\frac{v_{\mathrm{nf}}}{\propto_{\mathrm{nf}}} .
\end{aligned}
$$

Friction factors $(f)$ and Nusselt numbers $(\mathrm{Nu})$ for singlephase flow have been calculated from the following equations:

$$
\begin{aligned}
f & =[1.58 \ln \operatorname{Re}-3.82]^{-2}, \\
\mathrm{Nu} & =\frac{(0.125 f)(\operatorname{Re}-1000) \operatorname{Pr}}{1+12.7(0.125 f)^{0.5}\left(\operatorname{Pr}^{2 / 3}-1\right)} .
\end{aligned}
$$

Friction factor of each flow rate for nanofluid which can be found in single-phase flow cannot be used for calculating friction factor as well as Nusselt number as presented by Hussein [13].

$$
\begin{aligned}
f & =0.961 \operatorname{Re}^{-0.375} \phi^{0.052}, \\
\mathrm{Nu} & =0.074 \operatorname{Re}_{\mathrm{nf}}^{0.707} \operatorname{Pr}_{\mathrm{nf}}^{0.385} \phi^{0.074} .
\end{aligned}
$$




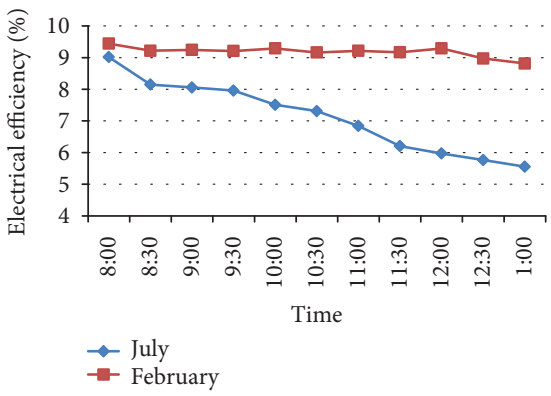

(a)

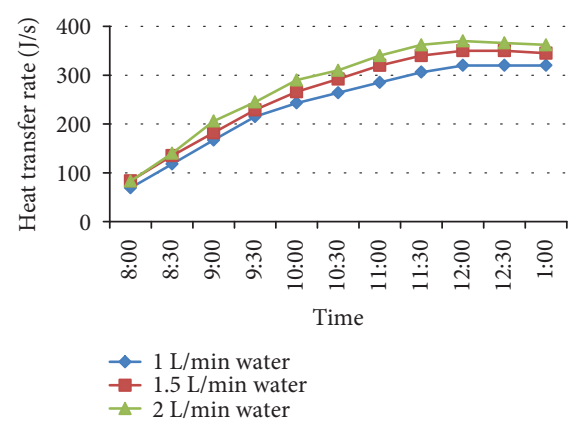

(b)

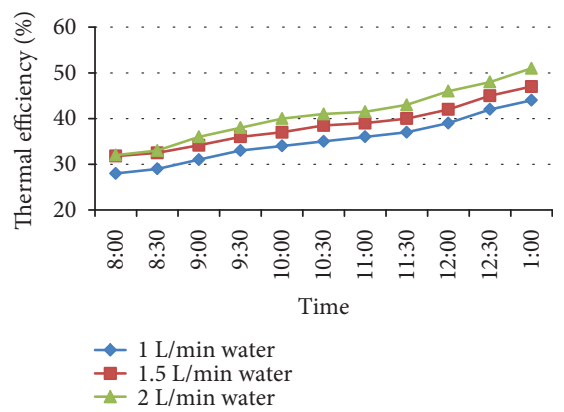

(c)

Figure 6: (a) Comparison of the electrical efficiency at climatic conditions. (b) Heat transfer rate with different mass flow rates. (c) Effect of the mass flow rates of water on the thermal efficiency.

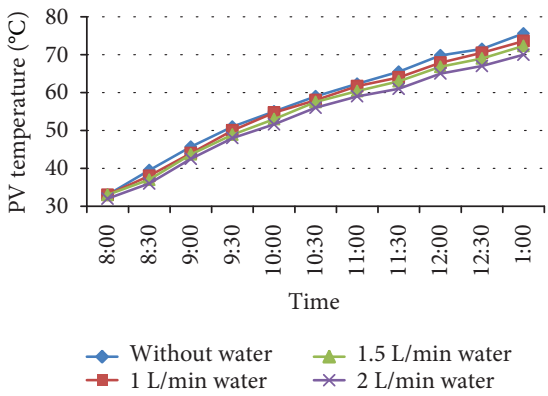

(a)

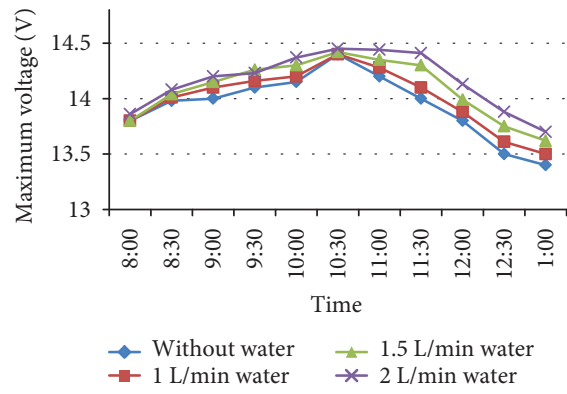

(b)

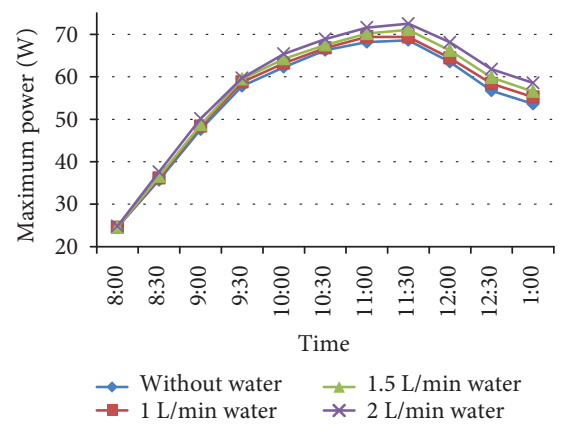

(c)

Figure 7: (a) Effect of mass flow rates on the PV temperature. (b) Effect of mass flow rates on the voltage. (c) Effect of mass flow rates on the PV power. 


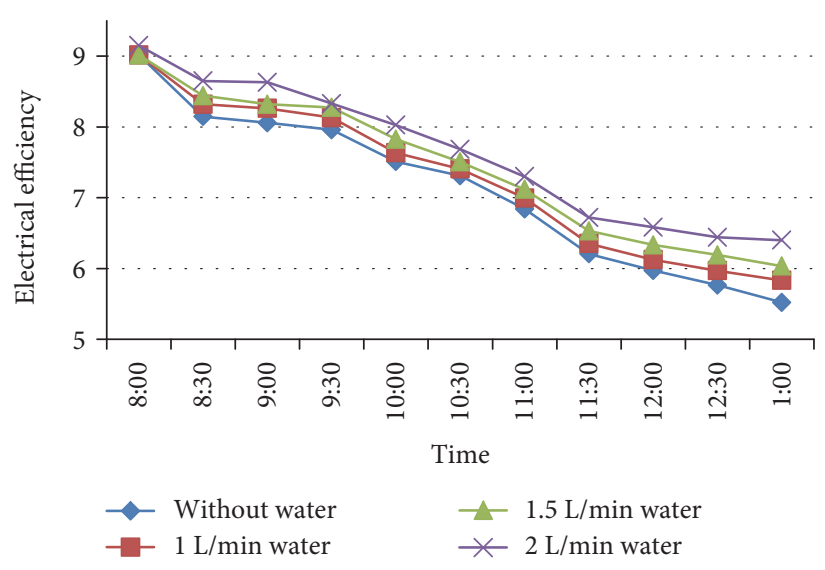

(a)

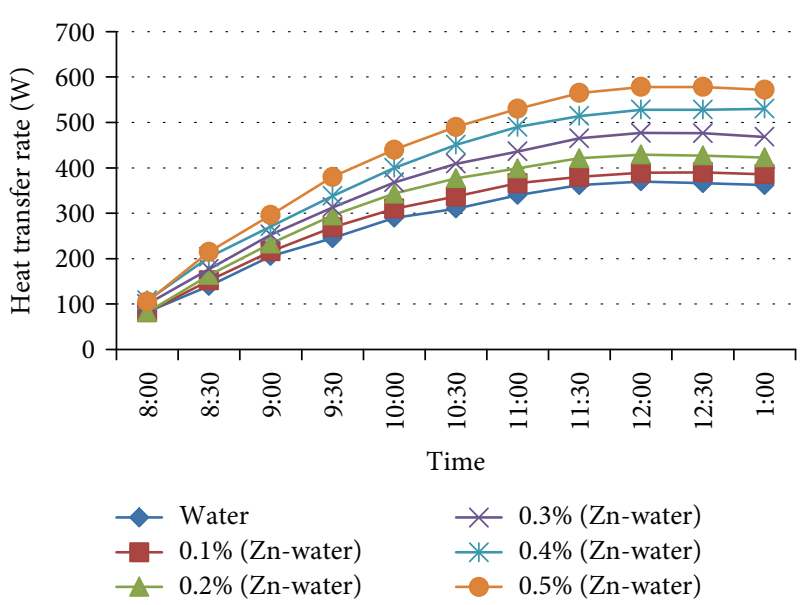

(b)

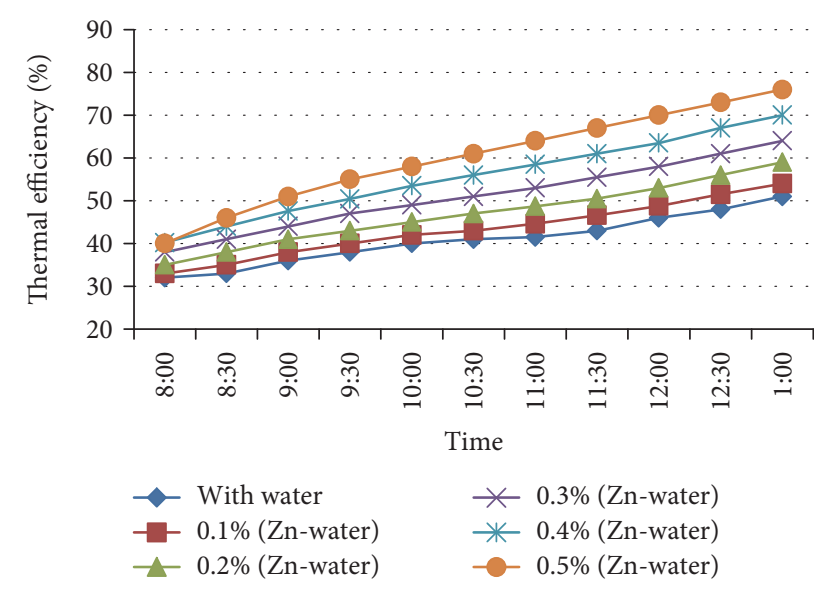

(c)

Figure 8: (a) Effect of mass flow rates on the electrical efficiency. (b) Heat transfer rate at constant flow rate $(2 \mathrm{~L} / \mathrm{min})$ at different nanofluid concentrations. (c) Effect of $\mathrm{Zn}-\mathrm{H}_{2} \mathrm{O}$ nanofluid at $2 \mathrm{~L} / \mathrm{min}$ on thermal efficiency.

\section{Material and Methods}

3.1. Experimental Setup. The prototype of $\mathrm{PV} / \mathrm{T}$ system is where the water pumping system was used for all experimental investigations of electrical and thermal effects on system performance and suggested improvements. The setup comprises PV panel, charge controller, battery, DC-DC boost converter, PMDC motor used as a pumping system load, copper pipes fixed on the backside of PV panel, and a radiator with a fan and circulation pump for cooling hot water. The experiment was performed on the site of Electromechanical Engineering Department, University of Technology, in summer and winter seasons.

The photograph of the setup as shown in Figures 1(a) and 1(b) explains the schematic diagram of the complete experimental setup. The major component of the experimental setup is the PV panel that produces direct current (DC) electricity. In this work, the SR-100S PV panel which was made from a monocrystalline semiconductor has been used. The PV panel consists $9 \times 6$ cells which have generated 100 Watts maximum power under standard test condition (STC) and typically can generate nearly $5.8 \mathrm{~A}$ at maximum solar radiation. The quantities measured during the experiment were as follows: (1) Digital solar meter mounted on the plane of a photovoltaic panel is used to indicate the change of solar irradiance. (2) Five K-type thermocouples connected to the 12-channel digital temperature recorder (type Lutron BTM4208SD) were used to measure the temperature of PV panel, working fluid, and ambient temperature. (3) The maximum current and voltage, short-circuit current and open-circuit voltage, of the PV panel were recorded manually using multimeters. (4) The mass flow rate of the working fluid $\left(\mathrm{Zn}-\mathrm{H}_{2} \mathrm{O}\right.$ nanofluid) was measured using flow rate meter.

3.2. PV/T Description. In this work, a specially made serpentine flow collector has been designed. The PV/T collector comprises PV module and thermal collector which are made of copper sheet and pipe. The copper sheet and the piping are paste directly to the back side of PV panel. Copper material has been used due to its high thermal conductivity with the pipe's inner diameter of $11 \mathrm{~mm}$ and thickness of $1 \mathrm{~mm}$ to transfer the temperature from PV panel to the working fluid. Thermal sink was used between the bottom surface of PV 


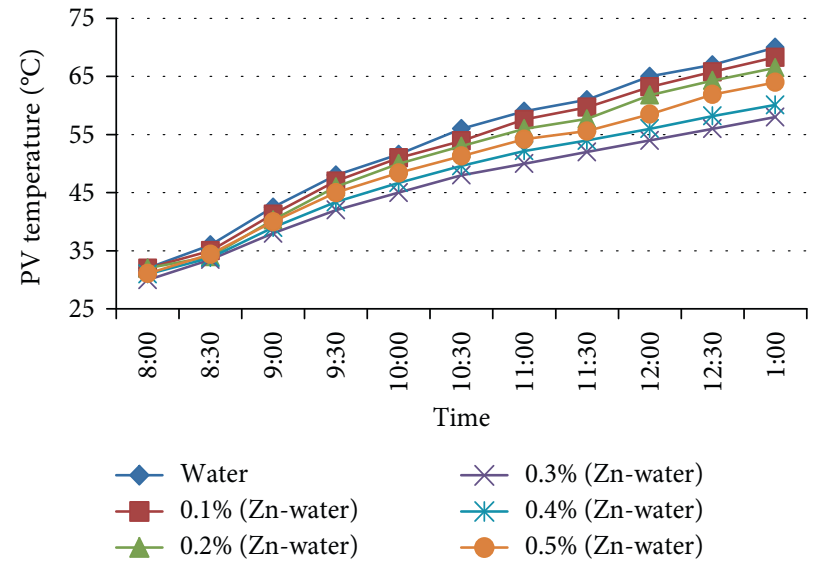

(a)

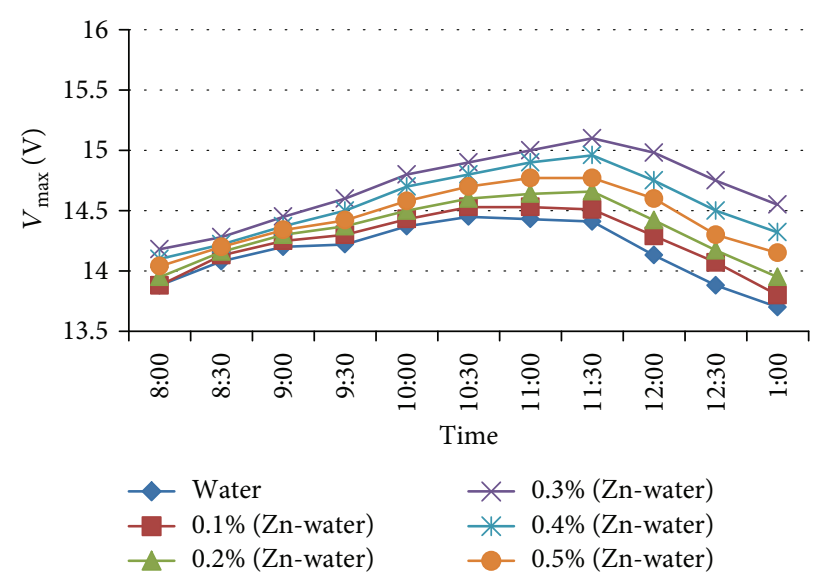

(b)

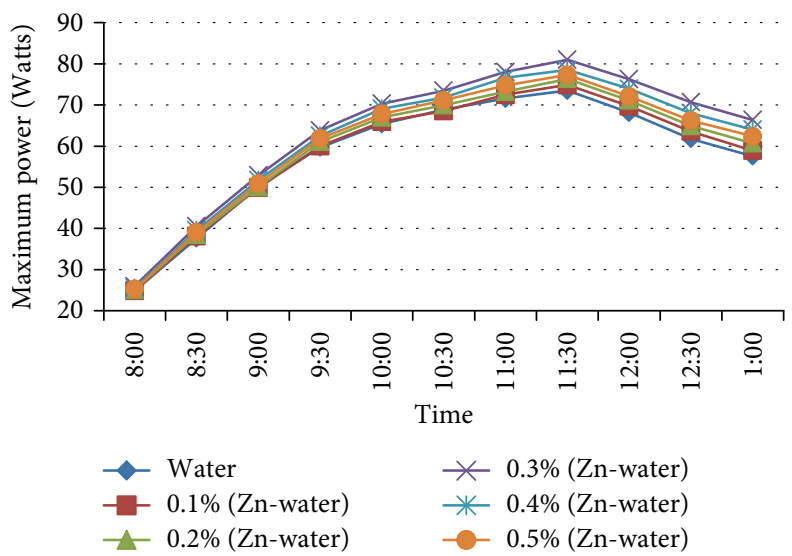

(c)

Figure 9: (a) Effect of $\mathrm{Zn}-\mathrm{H}_{2} \mathrm{O}$ nanofluid at $2 \mathrm{~L} / \mathrm{min}$ on the photovoltaic temperature. (b) Effect of $\mathrm{Zn}-\mathrm{H}_{2} \mathrm{O}$ nanofluid at $2 \mathrm{~L} / \mathrm{min}$ on the voltage. (c) Effect of $\mathrm{Zn}-\mathrm{H}_{2} \mathrm{O}$ nanofluid at $2 \mathrm{~L} / \mathrm{min}$ on the power.

panel and the surface of $2 \mathrm{~mm}$ copper plate to increase thermal conductivity.

The copper pipes are linked using a welding machine. The storage capacity of piping system is 1.5 liters welded on the copper sheet with a height and length and then fixed on the back surface of standard PV panel. The welding method is with $40 \%$ tin and $60 \%$ silver. The oscillatory flow has at least one inlet and outlet to permit working fluid to enter and to exit from the copper pipes, respectively. Water enters the pipes with low temperature and travel as hot water. The hot water can be consumed or stored for later use. However, this work is dedicated to water pumping system and thus there is no need for hot water output from the proposed $\mathrm{PV} / \mathrm{T}$ system. In this way, solar radiation energy can be fully used for solar heating applications. The dimension of the thermal collector is shown in Figure 2(a).

3.3. Preparation of Nanofluid. After studying the impact of a water-cooling technique on the performance of PV/T system, Zn-water nanofluid was prepared at five concentration ratios $(0.1,0.2,0.3,0.4$, and $0.5 \%)$ by mixing the particles with 1.5 liters of ionized water. Figure 2(b) shows that $\mathrm{Zn}$-water nanofluid has been prepared in the corrosion laboratory of the Materials Engineering Department at the University of Technology. Nanopowder was purchased, and a type of $\mathrm{Zn}$ nanoparticle was used in this study. The diameter of the nanoparticle is $30 \mathrm{~nm}$.

\section{Results and Discussion}

4.1. Simulation of the PV Output Characteristics. The PV Matlab model that has been developed is tested to assess the solar radiation effects and PV temperature variations. From the results, it notes that the current increases proportionally with the increase of solar radiation, but the voltage increases nonlinearly with solar radiation and then increases the level of power output as shown in Figure 3. On the other hand, the temperature primarily affects the PV voltage. The rising temperature of $\mathrm{PV}$ panel primarily influences the $\mathrm{PV}$ voltage more than the PV current. That reason subsequently leads to decrease the power. When the temperature of PV module increases from 25 to 85 at irradiation of $1000 \mathrm{~W} / \mathrm{m}^{2}$, the PV open-circuit voltage is decreased from 21.8 to 18.8 volts and this leads to decrease the PV power generated from 100 to 84 Watts which represents the variation of current-voltage $(I-V)$ and power-voltage $(P-V)$ 


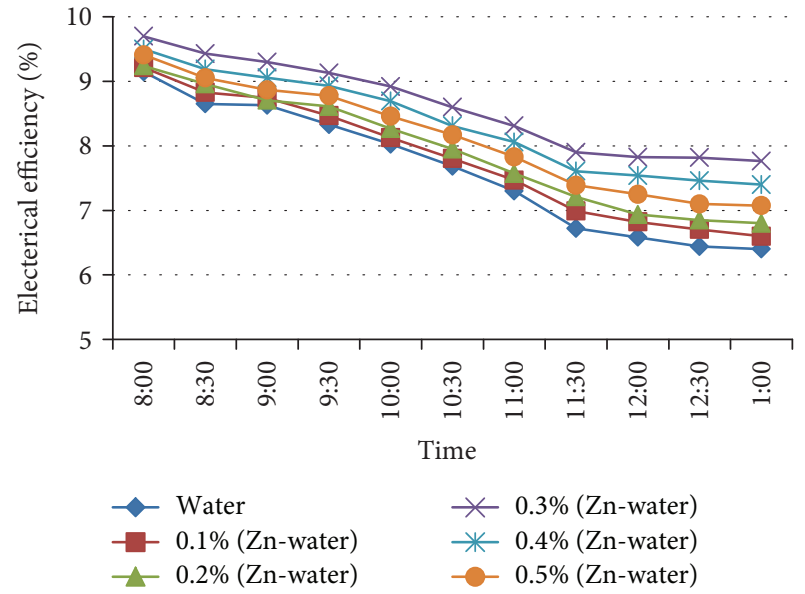

(a)

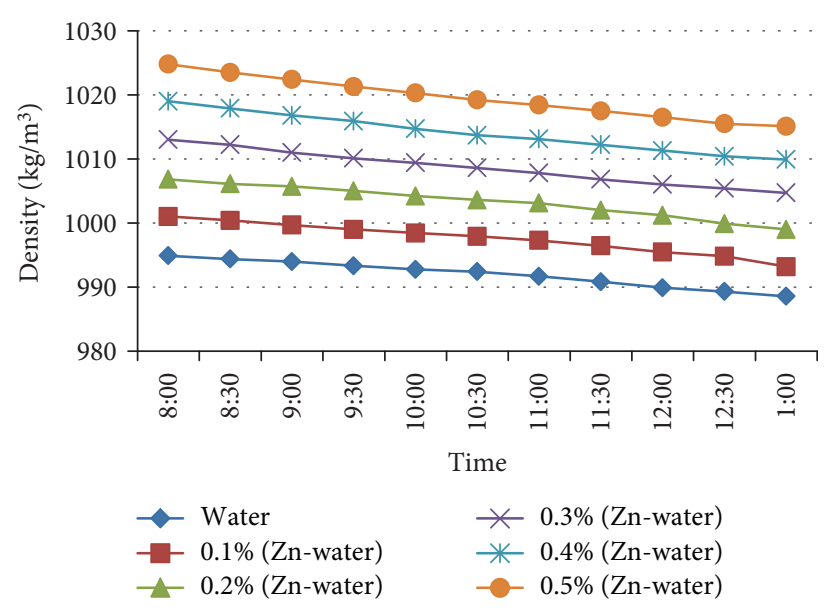

(b)

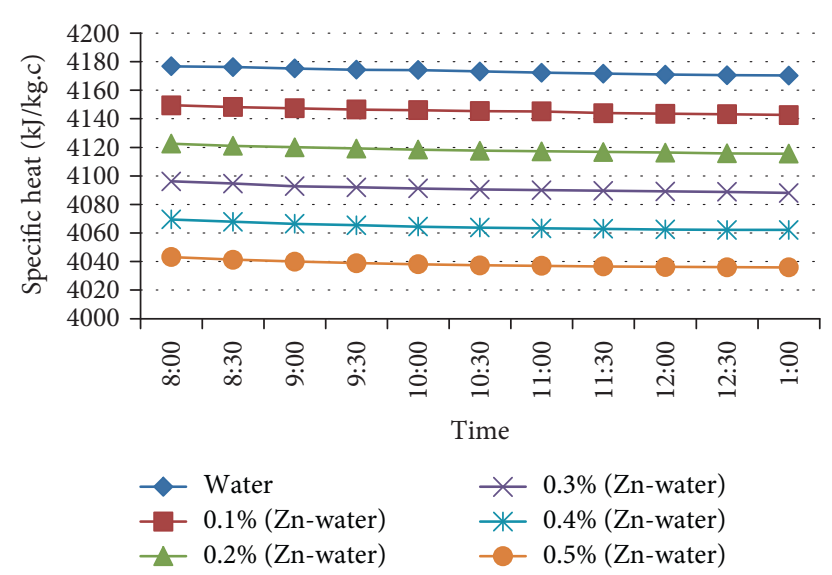

(c)

Figure 10: Effect of $\mathrm{Zn}-\mathrm{H}_{2} \mathrm{O}$ nanofluid concentrations at $2 \mathrm{~L} / \mathrm{min}$ on (a) electrical efficiency, (b) working fluid density, and (c) specific heat.

characteristics. After solving the governing equations of the electrical and thermal performance of the system as mentioned in the introduction section which helped to determine and obtained the results, the thermal performance of $\mathrm{PV} / \mathrm{T}$ system is shown in Figure 4.

4.2. PV Performance with Water-Cooling Technique. Figure 5 shows the temperature difference, voltage, and maximum power variations of the hybrid system $\mathrm{PV} / \mathrm{T}$, respectively. These curves represented the changing of temperature difference depending on the solar radiation and ambient temperature with time. The temperature difference between inlet and outlet is almost in linear relationship with the solar radiation at changing value of radiation from $200 \mathrm{~W} / \mathrm{m}^{2}$ to $900 \mathrm{~W} / \mathrm{m}^{2}$ and then falls to $700 \mathrm{~W} / \mathrm{m}^{2}$ nearly. It is observed that when the increase of flow rate causes a decrease in the output temperature and the temperature difference and when the decrease of flow rate leads to increase in the output temperature and the temperature difference and then gets the best thermal gain, this is due to the fluid which takes a long time to absorb heat from the surface of PV module.
Figure 6 shows that the $2 \mathrm{~L} / \mathrm{min}$ flow rate gives the best performance for the thermal efficiency of the $\mathrm{PV} / \mathrm{T}$ system due to the increase in heat transfer rate of fluid in pipes which represents that the $2 \mathrm{~L} / \mathrm{min}$ flow rate of working fluid (water) gives good improvement in current and voltage for photovoltaic/thermal system due to the reduction in photovoltaic temperature at this value of flow rate and the cooling process gives improvement on power generated from photovoltaic, but the better power produced at the $2 \mathrm{~L} / \mathrm{min}$ flow rate is because more heat dissipated in the radiator with increasing flow rate of working fluid circulated.

It is observed that the electrical efficiency of the PV module increases with increasing the flow rate of fluid. The best electrical efficiency is obtained at optimum flow rate $(2 \mathrm{~L} / \mathrm{min})$ because all the performance is improved at this rate. The results show that the operation of pumping system depends deeply on the performance of the photovoltaic system and the peak power of the photovoltaic system. The DC voltage influences the speed of running motor. It is observed that low voltage generated from PV module due to high operating temperature leads to a decrease in the output of DC pump, while high voltage leads to an increase 


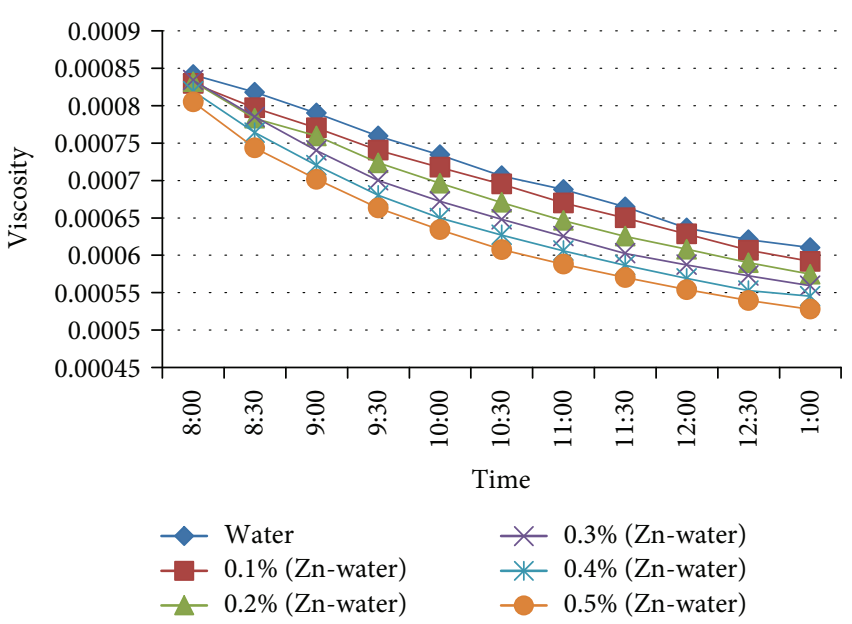

(a)

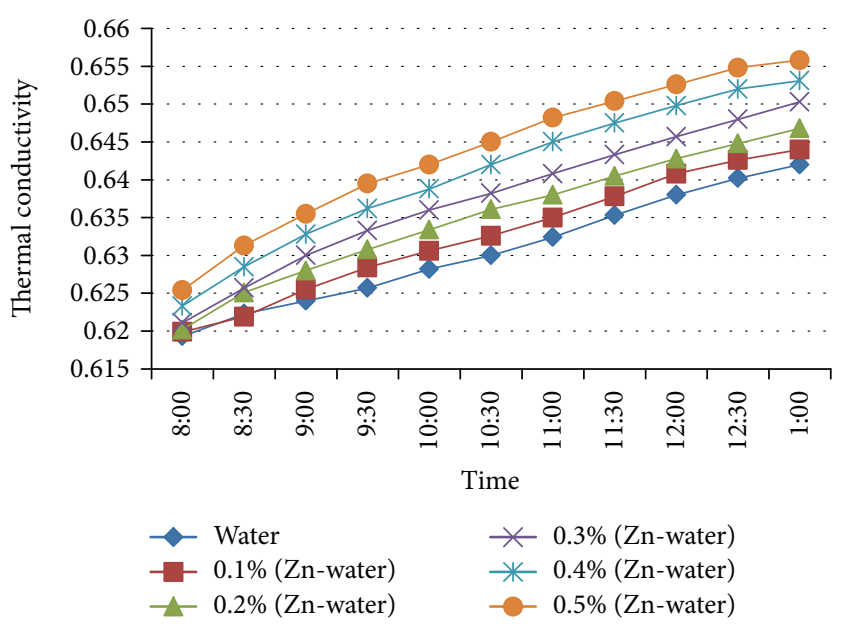

(b)

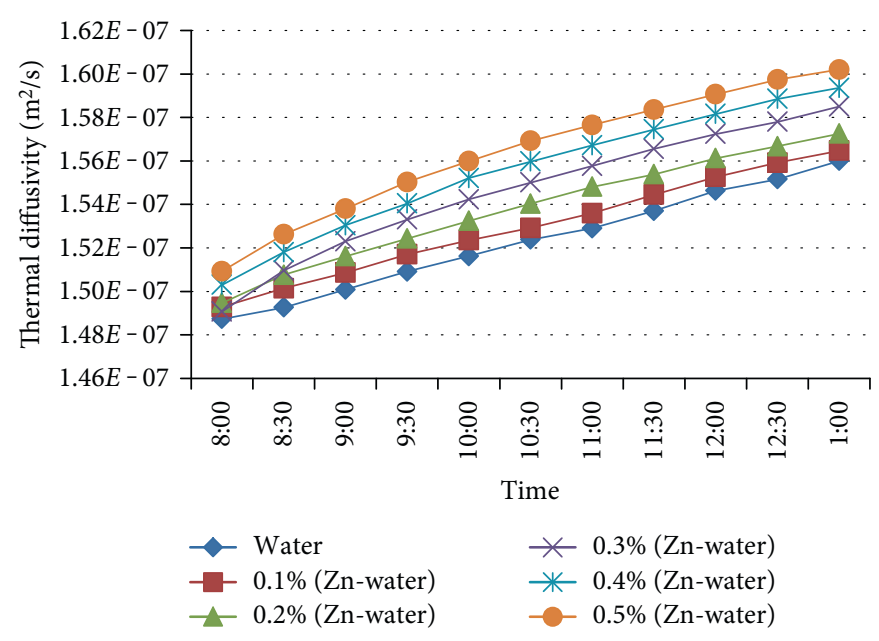

(c)

FIgURE 11: Effect of $\mathrm{Zn}-\mathrm{H}_{2} \mathrm{O}$ nanofluid at $2 \mathrm{~L} / \mathrm{min}$ on (a) viscosity, (b) thermal conductivity, and (c) thermal diffusivity.

in the output of DC pump. It is observed that circulating the fluid through pipes at photovoltaic cells' rear surface strongly enhances the performance of system and subsystem, since motor pump can receive most of the power of cells by improving the performance of $\mathrm{PV}$ module as shown in Figure 7.

4.3. PV Performance with the Use of $\mathrm{Zn}-\mathrm{H}_{2} \mathrm{O}$ Nanofluid. The thermal conductivity of $\mathrm{Zn}$ metal is higher than the water: 112.2 W/m.k for $\mathrm{Zn}$ metal while for the water, $0.596 \mathrm{~W} / \mathrm{m} . \mathrm{k}$. This feature gives an increase in the thermal conductivity of working fluid. Figure 8(b) shows that the heat transfer rate increases with the increase of volume concentration ratio of nanofluid because the nanofluid thermal conductivity increases as the concentration ratios of nanofluid increases and that led to an increase in the thermal performance of photovoltaic/thermal system as shown in Figure 8(c) that is due to the increase of heat transfer rate with the concentration ratio. It is found that $2 \mathrm{~L} / \mathrm{min}$ of mass flow rate gives the best thermal performance and electrical performance under water test of $\mathrm{PV} / \mathrm{T}$.
Figure 9 explains that the value $0.3 \%$ gives the best cooling for photovoltaic. This is due to the increase in thermal conductivity of $\mathrm{Zn}-\mathrm{H}_{2} \mathrm{O}$ nanofluid at this ratio which led to more absorption of heat from photovoltaic surface. If the concentration ratio increases more than $0.3 \%$, the PV temperature will increase because of the increase in density and viscosity of working fluid with the rising of concentration ratio, and this gives reverse impact of improvement. By decreasing PV temperature with the use of nanofluid, the maximum power produced from the PV module will be increased. It was noticed that the better maximum power generated is at $0.3 \%$ nanofluid concentration ratio because this volume ratio gives good cooling for PV module; also, it was observed that there is an improvement in $I_{\max }$ and $V_{\max }$ which leads to enhancement in PV power when using nanofluid and a good case at $0.3 \%$ concentration ratio. The electrical efficiency of PV module is improved by using nanofluid at $0.3 \%$ volume concentration ratio and reduced when it is greater than $0.3 \%$ because of the increase of PV temperature as the volume concentration ratio increases above $0.3 \%$, as shown in Figure 10. 


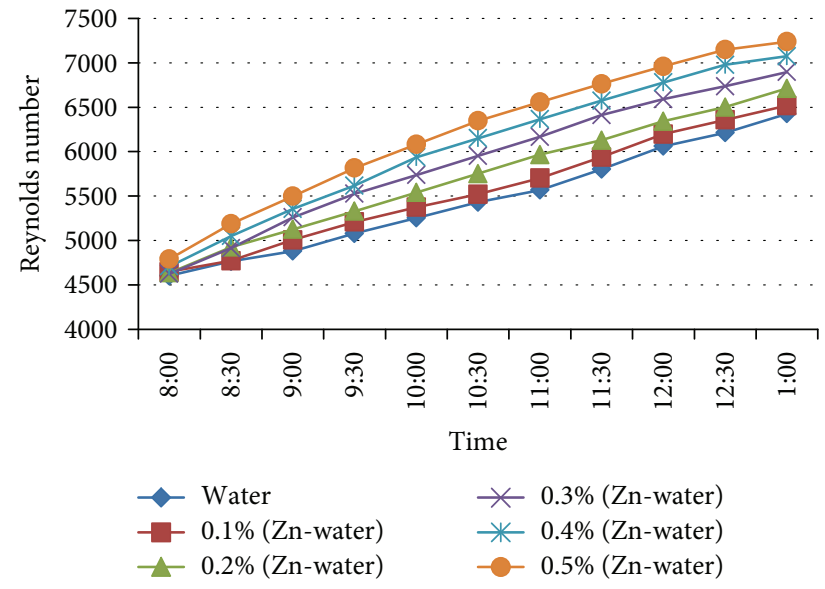

(a)

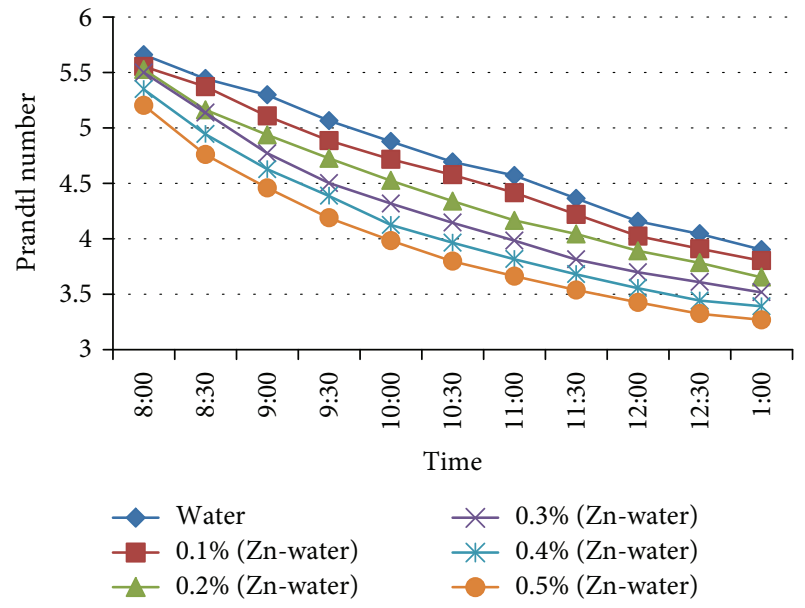

(b)

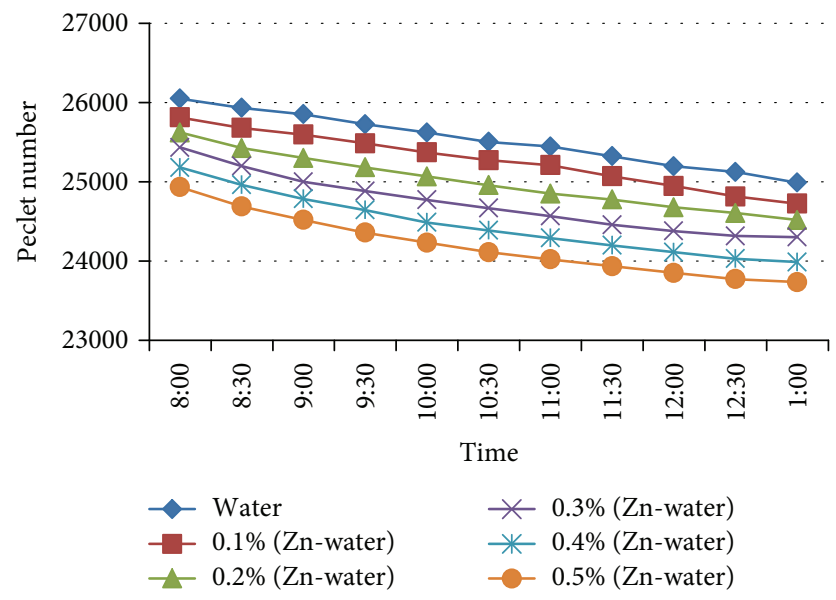

(c)

Figure 12: Effect of $\mathrm{Zn}-\mathrm{H}_{2} \mathrm{O}$ nanofluid at $2 \mathrm{~L} / \mathrm{min}$ on (a) Reynolds number, (b) Prandtl number, and (c) Peclet number.

4.4. Physical Properties of $\mathrm{Zn}-\mathrm{H}_{2} \mathrm{O}$ Nanofluid. All the physical properties of working fluid will change depending on the concentration ratio of nanoparticles such as density, specific heat, viscosity, and thermal conductivity. It was observed from the sketch that the variation of density of nanofluid is a function of volume concentration ratios and the density of water when increasing the temperature. Figure 11(a) represents the changes in specific heat of nanofluid with increasing the volume concentration ratios. This behavior is due to the change in density of nanofluid as a function of temperature. Figure 11(b) represents the viscosity of nanofluid as a function of volume concentration ratio. The results showed the decrease in nanofluid viscosity at all volume concentration ratios with rising temperature; this is explained by changing the physical properties of the water at rising temperature. Figure 11 shows the changes in thermal conductivity and thermal diffusivity of nanofluid, respectively, with increase in volume concentration ratios where the thermal conductivity is the most important in the physical properties of nanofluid, and it primarily depends on the temperature of fluid. It was observed that at higher temperature, there is greatest impact on these values and we noticed that with increasing the concentration ratios, the more heat are absorbed at the same time as compared with all values of volume concentration ratios, and this rise in temperatures leads to an increase in the thermal conductivity and thermal diffusivity of nanofluid, respectively. Figure 12 shows the influence of volume concentration ratios on Reynolds number; increasing concentration ratios led to increasing absorbing temperature, leading to increase in Reynolds number. This increase in Reynolds number is due to the reduction in viscosity of nanofluid and increase in density of nanofluid. Figure 12(c) represents the decreasing in Prandtl number with increasing in temperature for all volume concentration ratios; this is due to the increase in density and thermal diffusivity and the decline in viscosity with higher temperature. The influence of volume concentration ratios on Peclet number is shown in Figure 13. It is observed from the graph that the Peclet number decreased because of the increase in thermal diffusivity. The influence of volume concentration ratios as a function of temperature on the Nusselt number is shown in Figure 13(b). It was observed that the Nusselt number increased with volume concentration ratios $(0.1$, 


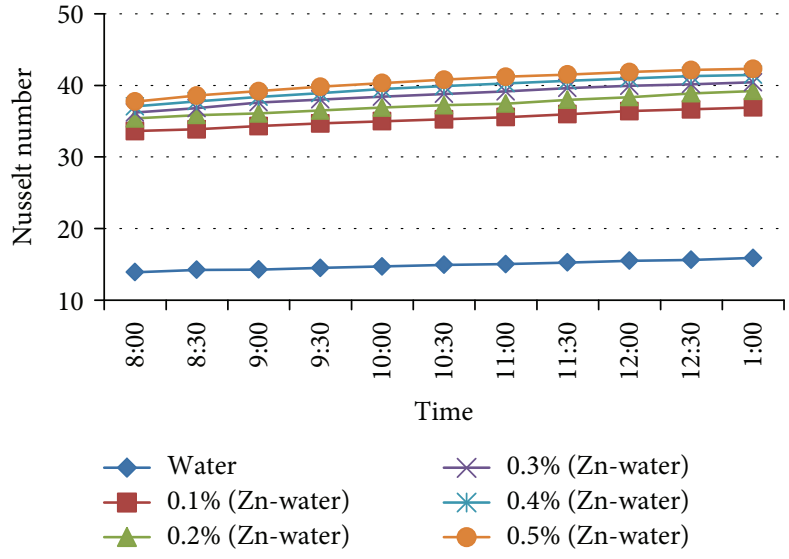

(a)

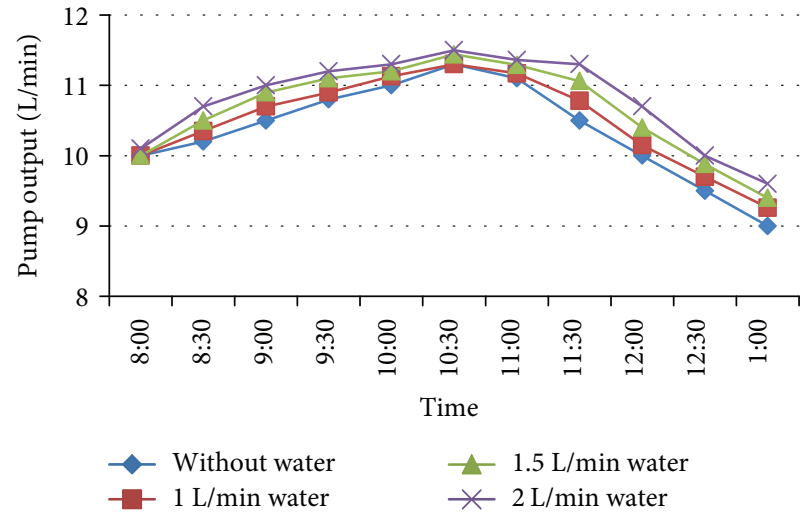

(b)

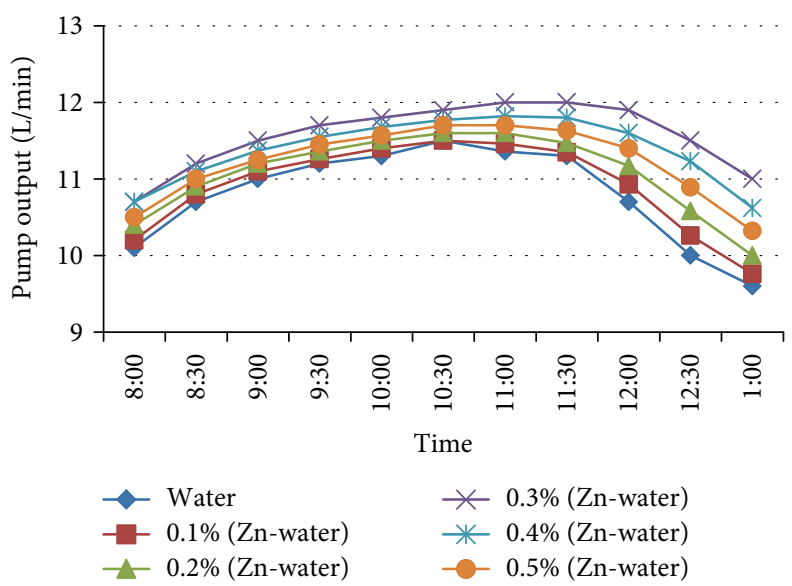

(c)

Figure 13: Effect of $\mathrm{Zn}-\mathrm{H}_{2} \mathrm{O}$ nanofluid at $2 \mathrm{~L} / \mathrm{min}$ on (a) Nusselt number, (b) pump output at different mass flow rates, and (c) pump output at constant mass flow rate $(2 \mathrm{~L} / \mathrm{min})$ with different concentration ratios.

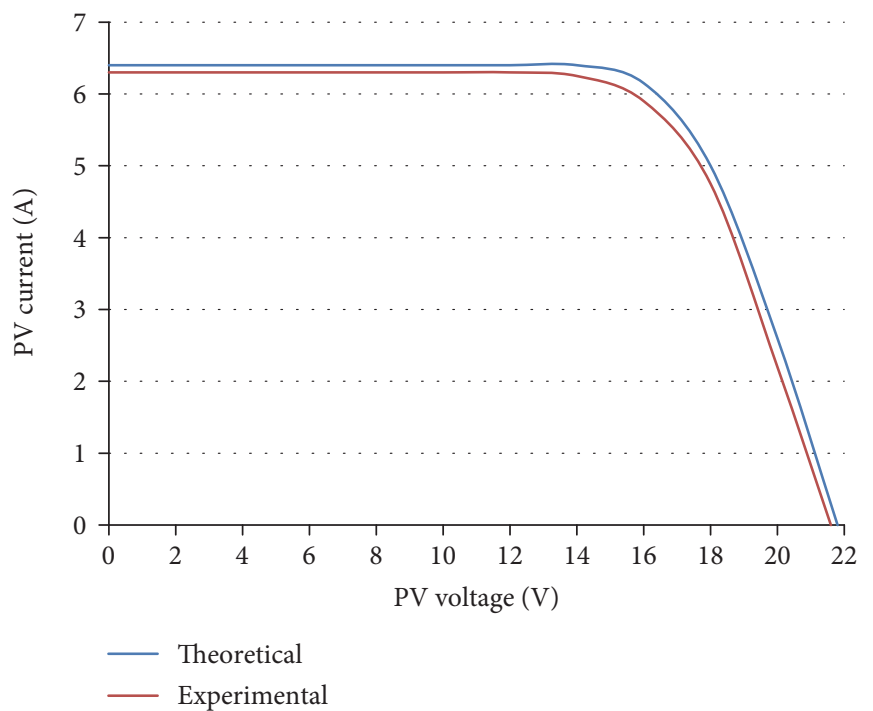

(a)

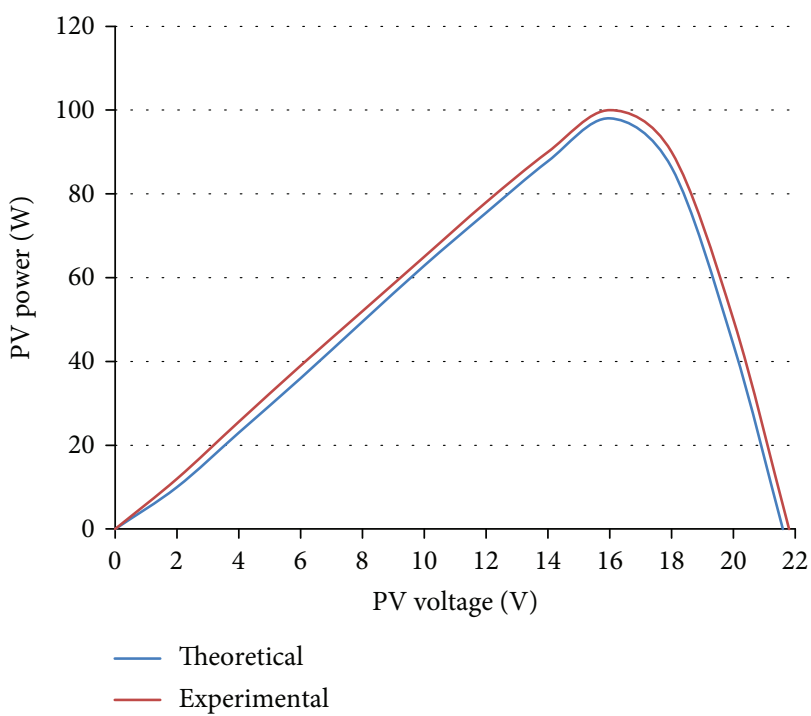

(b)

Figure 14: (a) Theoretical and experimental results comparison of $I-V$ at $25^{\circ} \mathrm{C}, 1000 \mathrm{~W} / \mathrm{m}^{2}$. (b) Theoretical and experimental results comparison of $P-V$ at $25^{\circ} \mathrm{C}, 1000 \mathrm{~W} / \mathrm{m}^{2}$. 


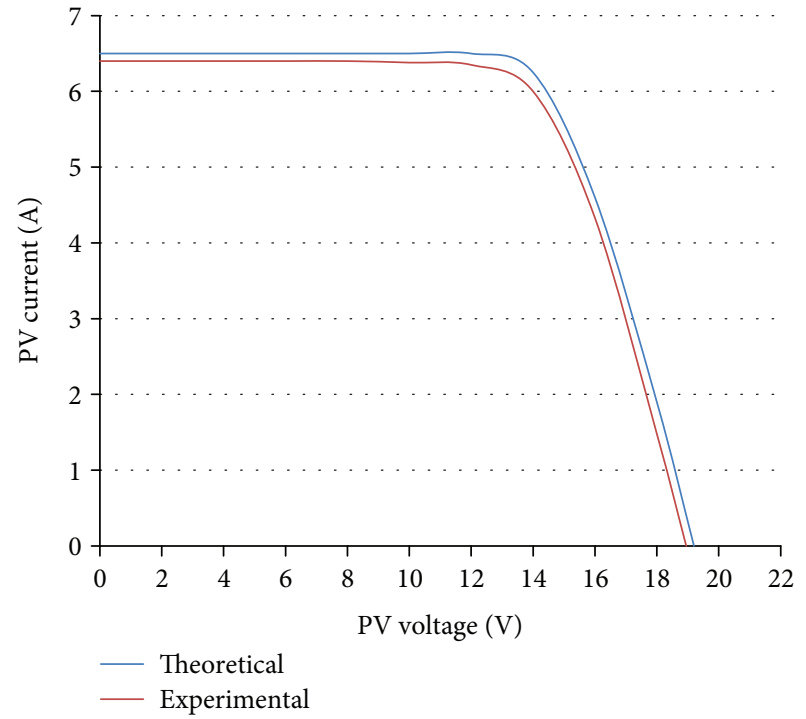

(a)

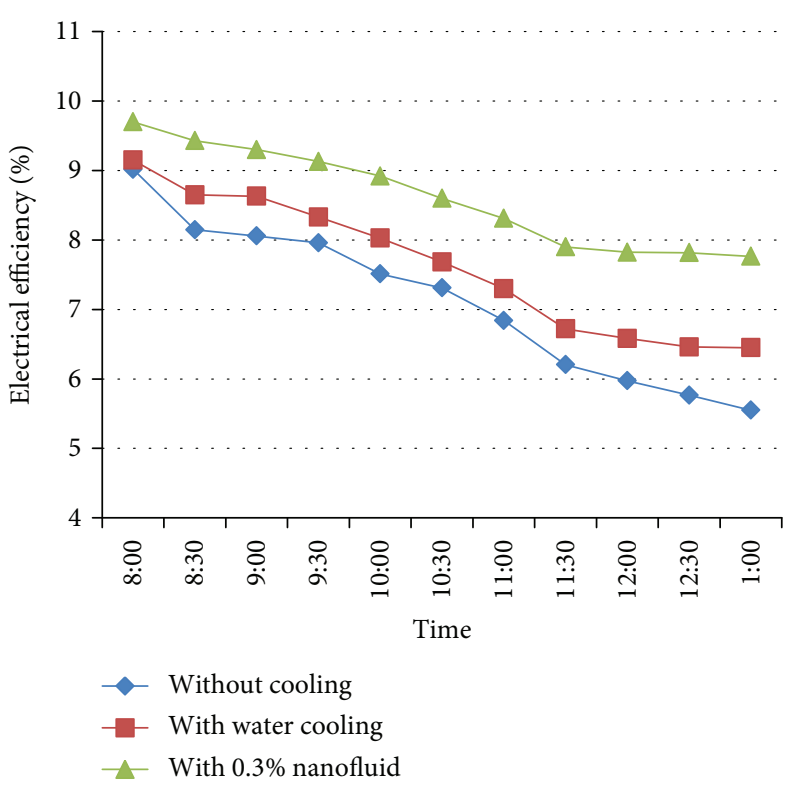

(b)

FIgURE 15: (a) Theoretical and experimental results comparison of $I-V$ at $1000 \mathrm{~W} / \mathrm{m}^{2}$ and $70^{\circ} \mathrm{C}$. (b) Comparison of electrical efficiency of $\mathrm{PV} / \mathrm{T}$ without water, with water $(2 \mathrm{~L} / \mathrm{min})$, and with $\mathrm{Zn}-\mathrm{H}_{2} \mathrm{O}$ nanofluid.

$0.2,0.3,0.4$, and $0.5 \%$ ). This increase is due to the increase of the Reynolds and Prandtl numbers with the rising temperature, and with increasing concentration ratios, this leads to increasing the value of Nusselt number.

4.5. PV Performance of Water Pumping System. In this work, we have tested the operation of pumping systems designed to supply water for drinking or irrigation. The results show that the operating of pumping system depends deeply on the performance of the photovoltaic system and the peak power of the photovoltaic system.

The goal achieved via this study is the investigation of solar radiation changing effects on the pumping system performances. The obtained results show that due to increasing solar radiation, the pump flow increased. The DC voltage influences the speed of running motor. It is observed that low voltage generated from PV module due to high operating temperature lead to a decrease in the output of DC pump, while high voltage lead to an increase in the output of DC pump. It is observed that circulating the fluid through pipes at the photovoltaic cells' rear surface strongly enhances the performance of systems and subsystems, since motor pumps can receive most of the power of the cells by improving performance of the PV module as shown in Figures 13(b) and 13(c).

4.6. Results Comparison. When comparing between the experimental results which have been measured manually as shown in Figures 15(a) and 15(b) with theoretical results obtained from simulation using Matlab/Simulink for PV characteristics under the conditions (1) effect of solar radiation at constant temperature $\left(25^{\circ} \mathrm{C}\right)$ and (2) effect of temperature at constant irradiation $\left(1000 \mathrm{~W} / \mathrm{m}^{2}\right)$. It can be noticed from these figures that the difference between experimental and theoretical results is about less than $2 \%$ which is quite acceptable.

\section{Conclusions}

The variations in solar radiation mainly influence the output current, while the changes in temperature mainly affect the output voltage. Hybrid PV/T systems are one of the methods used to enhance the electrical efficiency of panel then improve the photovoltaic water pumping system performance. The electrical and thermal efficiencies of the hybrid system will increase with increasing mass flow rate of water. At optimum flow rate of $2 \mathrm{~L} / \mathrm{min}$, electrical efficiency was $6.5 \%$ and thermal efficiency was $60 \%$. The results indicated that when nanofluid $(\mathrm{Zn})$ is used at various concentration ratios $(0.1,0.2,0.3,0.4$, and $0.5 \%)$ at $2 \mathrm{~L} / \mathrm{min}$ flow rate, the cell temperature dropped more significantly from $76^{\circ} \mathrm{C}$ to $58^{\circ} \mathrm{C}$ at an optimum concentration ratio of $0.3 \%$ nanofluid; this led to an increase in the electrical efficiency of PV panel to $7.8 \%$.

\section{Nomenclature}

A: $\quad$ Area of the PV module $\left(\mathrm{m}^{2}\right)$

$A_{\mathrm{c}}$ : $\quad$ Area of collector $\left(\mathrm{m}^{2}\right)$

$C_{\mathrm{pf}}:$ Heat capacity of the base fluid (J/kg.c)

$C_{\mathrm{pnf}}:$ Heat capacity of the nanofluid (J/kg.c)

$G: \quad$ Solar radiation $\left(\mathrm{W} / \mathrm{m}^{2}\right)$

$I_{\mathrm{m}}$ : Maximum current of PV (A)

$I_{\mathrm{sc}}: \quad$ Short-circuit current of solar cell (A)

$K_{\mathrm{f}}: \quad$ Thermal conductivity of base fluid (W/m.c) 
$K_{\mathrm{I}}: \quad$ Cell's short-circuit current temperature coefficient $(\mathrm{A} / k)$

$K_{\mathrm{nf}}: \quad$ Thermal conductivity of the nanofluid (W/m.c)

$K_{\rho}: \quad$ Thermal conductivity of the nanoparticle (W/m.c)

m: $\quad$ Mass flow rate $(\mathrm{kg} / \mathrm{s})$

$\phi$ : Volume concentration of the nanoparticles

$T_{\text {in }}$ : Inlet temperature of the working fluid $\left({ }^{\circ} \mathrm{C}\right)$

$T_{0}$ : Temperature of standard condition $\left(25^{\circ} \mathrm{C}\right)$

$T_{\text {out }}$ : Outlet temperature of working fluid $\left({ }^{\circ} \mathrm{C}\right)$

$V_{\mathrm{m}}: \quad$ Maximum voltage of $\mathrm{PV}(\mathrm{V})$

$V_{\mathrm{PV}}$ : Output voltage $(\mathrm{V})$

$\beta$ : $\quad$ Coefficient of silicon cell $\left(\beta=0.0045^{\circ} \mathrm{C}^{-1}\right)$

$\eta_{0}$ : Nominal electrical efficiency at standard conditions

$\mu_{\mathrm{nf}}: \quad$ Nanofluid viscosity $(\mathrm{kg} / \mathrm{m} . \mathrm{s})$

$\mu_{\mathrm{w}}: \quad$ Water viscosity $(\mathrm{kg} / \mathrm{m} . \mathrm{s})$

$\rho_{\mathrm{nf}}: \quad$ Density of the nanofluid $\left(\mathrm{kg} / \mathrm{m}^{3}\right)$

$\rho_{\mathrm{p}}$ : Density of the nanoparticles $\left(\mathrm{kg} / \mathrm{m}^{3}\right)$.

\section{Conflicts of Interest}

The authors declare that they have no conflicts of interest.

\section{References}

[1] S. K. Firth, Raising efficiency in photovoltaic systems: high resolution monitoring and performance analysis, [Ph.D. Thesis], De Montfort University, UK, 2006.

[2] A. Oi, Design and simulation of photovoltaic water pumping system, [MSc. Thesis], California Polytechnic State University, San Luis Obispo, California, 2005.

[3] H. Teo, Photovoltaic thermal (PV/T) system: effect of active cooling, [MSc. Thesis], National University of Singapore, Singapore, 2010.

[4] R. A. Taylor, P. E. Phelan, T. P. Otanicar et al., "Applicability of nanofluids in high flux solar collectors," Renewable and Sustainable Energy, vol. 3, no. 2, article 023104, 2011.

[5] M. Abdolzadeh and M. Ameri, "Improving the effectiveness of a photovoltaic water pumping system by spraying water over the front of photovoltaic cells," Renewable Energy, vol. 34, no. 1, pp. 91-96, 2009.

[6] W. A. EL-Basit, A. M. A. B. D. El-Maksood, and F. A. E.-M. S. Soliman, "Mathematical model for photovoltaic cells," Leonardo Journal of Sciences, vol. 23, pp. 13-28, 2013.

[7] S. Odeh and M. Behnia, "Improving photovoltaic module efficiency using water cooling," Heat Transfer Engineering, vol. 30, no. 6, pp. 499-505, 2009.

[8] H. Chaji, Y. Ajabshirchi, E. Esmaeilzadeh, S. Z. Heris, M. Hedayatizadeh, and M. Kahani, "Experimental study on thermal efficiency of flat plate solar collector using TiO2/ water nanofluid," Modern Applied Science, vol. 7, no. 10, p. 60, 2013.

[9] H. Ben, "Study of electrical and thermal performance of a hybrid PVT collector," International Journal of Electrical and Electronics, vol. 3, no. 4, pp. 95-106, 2013.

[10] I. E. El-Seesy, T. Khalil, and M. T. Ahmed, "Experimental investigations and developing of photovoltaic/thermal system," World Applied Sciences Journal, vol. 19, no. 9, pp. 1342-1347, 2012.

[11] R. Darby, Chemical Engineering Fluid Mechanics, Marcel Dekker, Inc, New York, 2nd edition, 2001.
[12] J. Albadr, "Heat transfer through heat exchanger using Al2O3 nanofluid at different concentrations," Case Studies in Thermal Engineering, vol. 1, no. 1, pp. 38-44, 2013.

[13] A. M. Hussein, "Experimental measurements of nanofluids thermal properties," International Journal of Automotive and Mechanical Engineering (IJAME), vol. 7, pp. 850-863, 2013. 

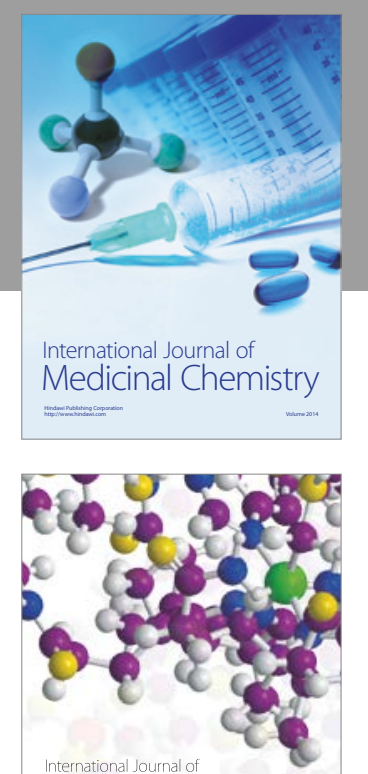

Carbohydrate Chemistry

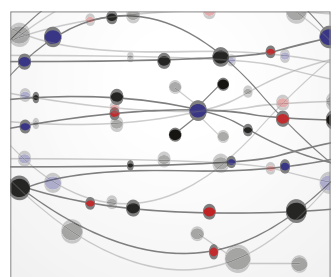

The Scientific World Journal
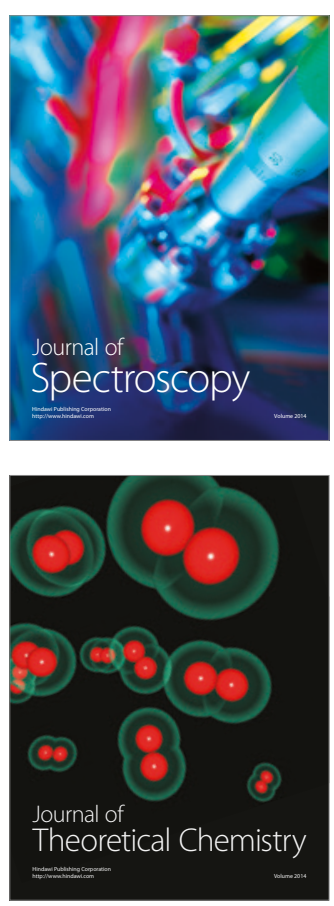
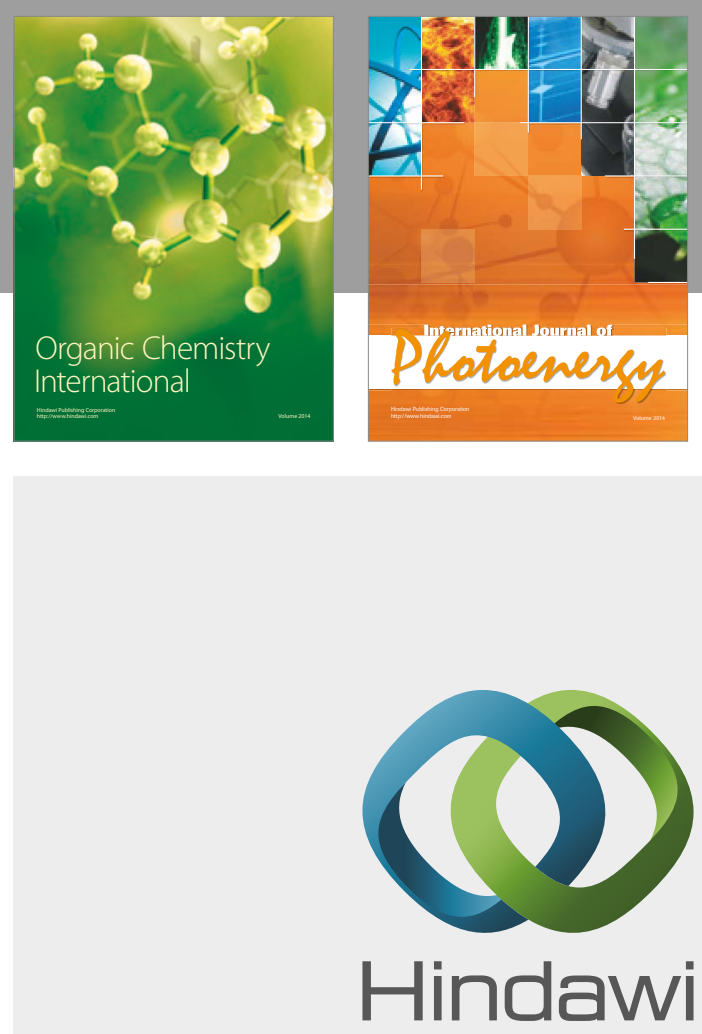

Submit your manuscripts at

https://www.hindawi.com

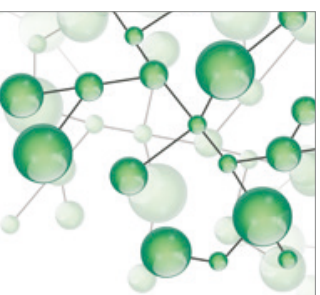

International Journal of

Inorganic Chemistry

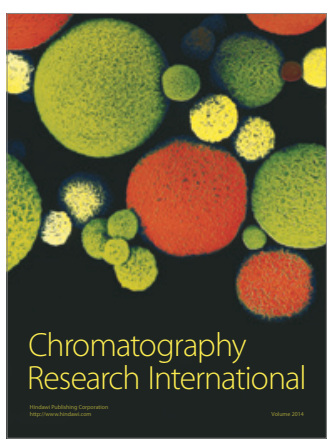

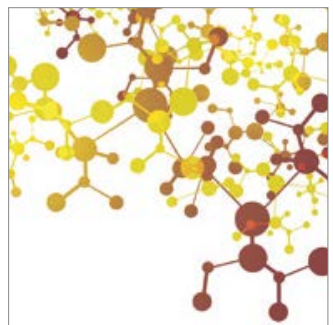

Applied Chemistry
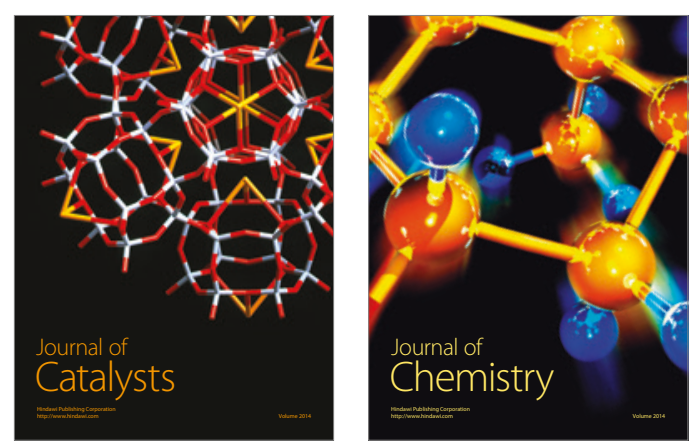
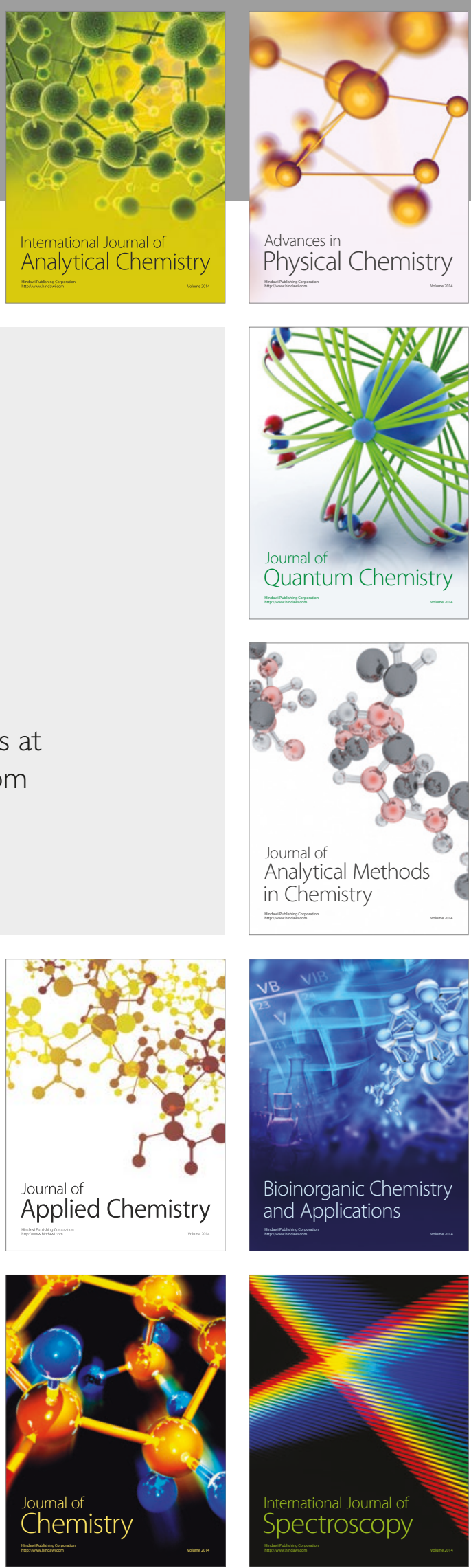